\title{
Når tvang er nødvendig
}

I løpet av 1800-tallet fikk de fleste europeiske land en egen epidemilovgivning for å bekjempe epidemiske sykdommer, inkludert syfilis og andre seksuelt overførbare sykdommer. Disse lovene ga myndighetene vidtgående fullmakter til å gripe inn overfor smittede personer - med tvangsundersøkelser, tvungen isolasjon og andre tvangstiltak.

Også Norge fikk en rekke slike lover. Smittevernloven som trådte i kraft 1. januar 1995, avløste sunnhetsloven av 1860 og hele sju særlover, blant annet om tuberkulose og kjønnssykdommer (1). Hensikten var først og fremst å beskytte samfunnet mot smitteførende individer. Det var liten oppmerksomhet rundt de etter hvert slumrende tvangsbestemmelsene i den gamle epidemilovgivningen inntil aids rammet Norge og førte til en heftig og polarisert debatt om bruk av tvangsmidler i aidsbekjempelsen utover i 1980-årene.

Noen tilhengere av tvangsmidler ønsket å bruke bestemmelsene i kjønnssykeloven på hivsmittede. Siden helsejurister mente at dette ikke var mulig, sendte helsemyndighetene ut på høring et lovutkast om en ny lov rettet mot hivepidemien. Høringsuttalelsene var nokså ublide, og lovforslaget ble skrinlagt. En bidragende årsak til dette var at den nye smitteloven nå var på trappene. Også smittevernloven inneholder bestemmelser om tvangstiltak, samlet i $\S 5$, der $\S 5-2$ omhandler tvungen unders $ø$ kelse/kortvarig isolasjon i sykehus og §5-3 tvungen isolering i sykehus. Grunnlaget for bruk av tvang er at tiltaket er «nødvendig for å forebygge en allmennfarlig smittsom sykdom eller motvirke at den blir overført». I forarbeidene til loven er det grundig understreket at tvang bare skal brukes som siste utvei når frivillige tiltak ikke har ført frem. I dette nummer av Tidsskriftet gir Tore Steen \& Trude Arnesen en oversikt over henholdsvis tvangsbestemmelsene i smittevernloven §5 (2) og hvordan disse bestemmelsene er blitt anvendt i perioden 1995-2013 (3).

Da smittevernloven ble innført, var det en del frykt for at tvangsbestemmelsene særlig ville bli brukt mot hivsmittede. Denne uroen har vist seg helt ubegrunnet. Loven har hittil kun vært anvendt på 12 personer, hvorav bare én var hivsmittet. De øvrige hadde tuberkulose, de fleste med smittsom lungeaffeksjon. I disse 11 tilfellene ble det truffet to vedtak om tvangsundersøkelse og kortvarig isolering og ni om tvungen isolering, som etter §5-3 i første omgang er inntil tre uker. Det var kun to vedtak om forlenget isolering. Etter §5-2 er det truffet meget få hastevedtak.

På bakgrunn av sine funn spør Steen \& Arnesen om tvangsbestemmelsene i smittevernloven har vært benyttet for sjelden og for lite effektivt. Forfatterne finner nemlig at hele 56 tuberkulosepasienter fra Tuberkuloseregisteret er registrert som «forsvunnet fra behandling», hvorav åtte hadde en multiresistent form. Dette er en uakseptabel situasjon, og det er rimelig å spørre om ikke tvangstiltak kunne vært anvendt $\mathrm{i}$ en rekke av tilfellene som var «forsvunnet fra behandling». Fem av disse pasientene var blant de 11 der tvangstiltak var blitt brukt. Kunne man her ha forutsett behandlingsavbrudd og forlenget isoleringen for å sikre at behandlingen ble fullført?

Fylkesnemnda for sosiale saker i Oslo og Akershus fungerer som nasjonal smittevernnemnd som skal behandle anmodning om tvangstiltak. Steen \& Arnesen fant at det gikk 4-19 dager, median 11 dager, fra begjæring ble fremmet av kommunelege (smittevernlege) til møte i nemnda, til tross for at loven fastslår at nemnda skal komme sammen «så snart som mulig». Fra møte til vedtak gikk det videre $0-3$ dager, median 1 dag, mens loven fastslår at vedtak skal gjøres «umid- delbart». Man må gi forfatterne rett $i$ at denne tregheten i smittevernnemndas funksjon ikke er akseptabel når det virkelig er behov for tvangstiltak for å forebygge spredning av alvorlig, allmennfarlig smittsom sykdom. Samtidig benyttes adgangen til hastevedtak for tvangsundersøkelse/kortvarig isolasjon påfallende sjelden. I tillegg kommer det eiendommelige faktum at smittevernloven ikke tillater hastevedtak etter $§ 5-3$, dvs. når smittetilstanden er påvist.

Bruk av tvangstiltak for å bekjempe smittsomme sykdommer, slik de er utformet i smittevernloven $\S 5-2$ og $§ 5-3$, representerer alvorlige inngrep i enkeltmenneskers rettigheter. De bør selvsagt brukes kun når frivillighet ikke har ført frem og de anses som helt nødvendige for å beskytte samfunnet. Men når de først anvendes, må dette skje med maksimal effektivitet. Steen \& Arnesens funn tyder på at bruk av tvangstiltak i perioden 1995-2013 gjennomgående har vært nokså halvhjertet i de få tilfellene der vedtak om tvang i det hele tatt ble fattet. Videre får man mistanke om at tvangsbestemmelsene er blitt anvendt for sjelden.

Selv om lovteksten tilsynelatende ikke sier noe om dette, er loven etter hvert tolket slik at tvangstiltak bare kan anvendes overfor mulige bærere av kroniske, smittsomme sykdommer hvis de viser tegn på aktiv sykdom (4). Infeksjonsmedisinsk og epidemiologisk er dette selvsagt ikke holdbart hvis man ønsker å forebygge smitte. Det er mulig at den nevnte lovtolkingen reflekterer den opprinnelige frykten for at tvangsbestemmelsene skulle bli brukt ved hivinfeksjon.

Smittevernloven er sentral i bekjempelsen av epidemiske sykdommer. Lovens virkemidler må være tilpasset både den nåværende epidemiologiske situasjonen og fremtidige nye epidemier som uten tvil vil komme. Selv om tvangstiltak neppe noen gang vil være et sentralt virkemiddel, vil også denne type tiltak være nødvendige i spesielle situasjoner der samfunnsbeskyttelse må gå foran individets rettigheter. Det er vesentlig at tvangsmidler brukes så effektivt og rasjonelt som mulig, samtidig som rettssikkerheten ivaretas. I lys av Steen \& Arnesens funn er det grunn til å vurdere en justering av smittevernloven, eventuelt forskrifter basert på loven, og samtidig diskutere tolkingen av visse punkter.

\section{Stig S. Frøland}

s.s.froland@medisin.uio.no

Kjønstad A, Mellbye F. AIDS og JUSS. Kampen mot smittsomme sykdommer fra Svartedauen til HIV-epidemien. Oslo: Universitetsforlaget, 1987.

2. Steen TW, Arnesen TM. Smittevernloven og tvang. Tidsskr Nor Legeforen 2014 134: $1371-2$

3. Steen TW, Arnesen TM. Tvangstiltak etter smittevernloven 1995-2013. Tidsskr Nor Legeforen 2014; 134: 1357-60.

4. Tveitan K. Lov om vern mot smittsomme sykdommer (Smittevernloven) (Lov av 05.08.1994 nr. 55). Kommentarutgave. Oslo: Norsk lovkommentar, Gyldendal, 2003

Podkast på www.tidsskriftet.no 